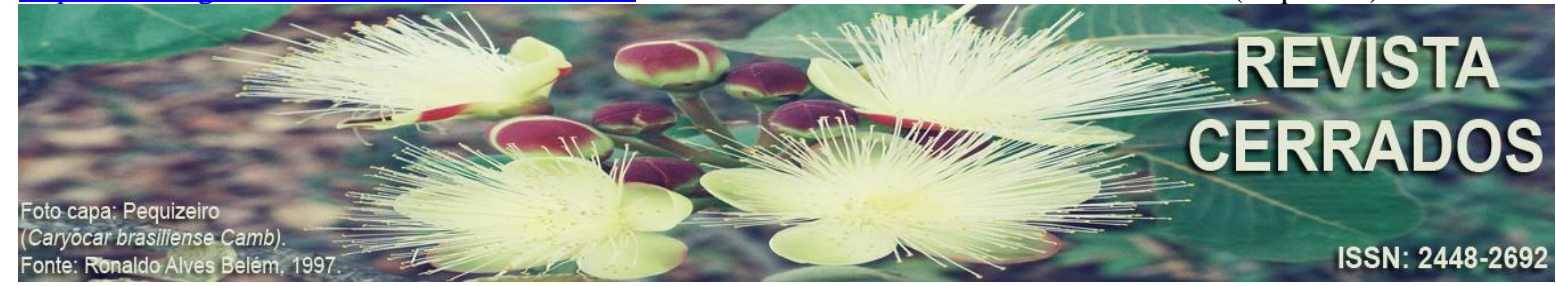

\title{
OS "SEM RIO": populações desterritorializadas pelo desastre ambiental de Mariana
}

\section{THE "RIVERLESS": populations deterritorialized by the environmental disaster of Mariana}

\section{LOS "SIN RÍO": poblaciones desterritorializadas por el desastre ambiental de Mariana}

\author{
João Mendes da Rocha Neto \\ Universidade de Brasília - UnB, Brasília, Distrito Federal, Brasil \\ E-mail: <jmdrn@uol.com.br>.
}

\begin{abstract}
RESUMO
Em 2015, o Brasil foi atingido por um dos maiores desastres ambientais de sua história com a ruptura da Barragem de Fundão, no estado de Minas Gerais. O episódio descortinou uma face da apropriação do território pelas grandes corporações, enfatizando o acidente enquanto processo de desterritorialização. Nesse sentido, o presente artigo possui a intenção de discutir a desterritorialização a partir das falas de atingidos e das imagens do território, refletindo sobre múltiplas manifestações. Para tanto, foi realizada uma revisão bibliográfica com autores de campos diversos do conhecimento, que permitem o debate conceitual, mas também contribuem para contextualizar o objeto estudado. Posteriormente, caracterizou-se o evento com levantamento de dados baseados em documentos e sítios eletrônicos de órgãos governamentais que estão atuando na reparação dos efeitos do desastre. Finalmente os registros fotográficos e entrevistas in loco permitiram discutir o arcabouço conceitual e a percepção sobre evento enquanto processo de despojo territorial. As conclusões do artigo revelam a imposição da lógica territorial das mineradoras e um ambiente institucional que não consegue promover as reparações sociais e ambientais decorrentes do desastre, repercutindo em uma situação de instabilidade para os atingidos, que mescla apatia pelo território relacional perdido e esperança por uma nova territorialidade.
\end{abstract}

Palavras-chave: Território. Desastre ambiental. Mariana-MG. Territórios da mineração. Rio Doce.

\section{ABSTRACT}

In 2015, Brazil witnessed what would be the one of the biggest environmental disasters in its history, with the rupture of the Fundão dam in the state of Minas Gerais. In addition to the 
ROCHA NETO, J. M.

Os "sem rio": populações desterritorializadas pelo desastre ambiental de Mariana

deaths directly caused by the collapse of the dam wall and the population of the downstream village of Bento Rodrigues, the event extended tailings of ore through the gutter of the Doce River for more than 800 kilometers. Such a disaster has immediate effects and others that manifest over time, highlighting the importance of such a body of water for the territory. In this sense, the article discusses, from the concept of territory, some of its developments from the perspective of the event, reflecting the scales of the problem and its different and complex forms of manifestation. To this end, a literature review was conducted with the authors discussing the topic; subsequently, a characterization of the event will be carried out, with data collection in documents and electronic websites of public agencies that are acting to repair the effects of the disaster; finally, a relationship of the concepts will be presented with some photographic records and on-site interviews that show how the event seen as a process of territorial dispossession.

Keywords: Territory. Environmental disaster. Mariana-MG. Mining territories. Doce River.

\section{RESUMEN}

En 2015, Brasil sufrió uno de los mayores desastres ambientales de su historia con la ruptura de la presa Fundão, en el estado de Minas Gerais. El episodio reveló un rostro de apropiación territorial por parte de las grandes corporaciones, enfatizando el accidente como un proceso de desterritorialización. En este sentido, el presente artículo pretende discutir la desterritorialización a partir de los discursos de los afectados y las imágenes del territorio, reflexionando sobre múltiples manifestaciones. Para ello, se realizó una revisión bibliográfica con autores de diferentes campos del conocimiento, que permiten el debate conceptual, pero también contribuyen a contextualizar el objeto estudiado. Posteriormente, el evento se caracterizó por la recolección de datos basados en documentos y sitios web de agencias gubernamentales que están trabajando para reparar los efectos del desastre. Finalmente, los registros fotográficos y las entrevistas in situ permitieron discutir el marco conceptual y la percepción del evento como un proceso de despojo territorial. Las conclusiones del artículo revelan la imposición de la lógica territorial de las empresas mineras y un entorno institucional que no promueve las reparaciones sociales y ambientales derivadas del desastre, reflejándose en una situación de inestabilidad para los afectados, que mezcla la apatía por el territorio relacional perdido y la esperanza de un nueva territorialidad.

Palabras clave: Territorio. Desastre ambiental. Mariana-MG. Territorios de la minería. Río Doce.

\section{CONSIDERAÇÕES INICIAIS}

A atividade mineradora no Brasil vem se apropriando de extensas áreas e impondo sua lógica aos territórios, modificando não somente as paisagens, mas, sobremaneira, interferindo nas relações sociais, com uma relevante participação do poder público por intermédio de suas políticas públicas. Essa territorialização pautada pela atividade 
ROCHA NETO, J. M.

Os "sem rio": populações desterritorializadas pelo desastre ambiental de Mariana

mineradora tem se mostrado cheia de situações conflituosas, considerando a expressividade do setor para a economia do país, sob o comando de grandes corporações mundiais.

Apesar de o setor ser marcado por alguns acidentes, foi em novembro de 2015 que o Brasil assistiu àquele que seria, até então ${ }^{1}$, o maior desastre ambiental de sua história, com a ruptura da Barragem do Fundão, no estado de Minas Gerais, pertencente a Samarco Mineração S/A. Além das mortes causadas diretamente pelo desmoronamento da parede da barragem e seus reflexos sobre a população do povoado de Bento Rodrigues, que localizavase a jusante, o evento espalhou rejeitos de minério por toda calha do rio Doce, ao longo de mais de 800 quilômetros.

Nesse sentido, o objetivo do presente artigo é discutir a desterritorialização, causada pelo desastre ambiental, problematizando a dependência dos territórios em relação à atividade mineradora, mas conferindo ênfase à análise desse processo a partir das falas dos atingidos, referidos por elementos conceituais que caracterizam as mudanças resultantes da ruptura da Barragem.

Para tanto, foi realizada uma revisão bibliográfica com autores que discutem a temática; posteriormente, o evento foi caracterizado com levantamento de dados, baseado em documentos e sítios eletrônicos de órgãos governamentais que estão atuando na reparação dos efeitos do desastre; e, finalmente, foi apresentada uma relação dos conceitos com alguns registros fotográficos e entrevistas in loco, que evidenciam como o evento é percebido enquanto processo de despojo territorial.

\section{O território e suas derivações conceituais: o ponto de partida para entender a questão}

Visto como um dos pilares conceituais da geografia, o conceito de território sofreu mudanças, mas sempre esteve relacionado à questão do poder e, portanto, da possibilidade de alguns atores estabelecerem uma posição de hegemonia frente aos demais, conforme demonstrado por Saquet e Silva:

Encontrar uma definição única para espaço, ou mesmo para território (...) é tarefa árdua, pois cada categoria possui diversas acepções, recebe diferentes elementos de forma que toda e qualquer definição não é uma definição imutável, fixa, eterna; ela é flexível e permite mudanças. Isso significa que os conceitos têm diferentes

\footnotetext{
${ }^{1}$ Depois ocorreu, em janeiro de 2019, o desastre da Barragem do Feijão, em Brumadinho/MG que deixou mais de 270 mortos e o derramamento de óleo na costa brasileira, que durou alguns meses do segundo semestre de 2019.

Revista Cerrados, Montes Claros/MG, v. 18, n. 02, p. 152-182, jul./dez.-2020.
} 
ROCHA NETO, J. M.

Os "sem rio": populações desterritorializadas pelo desastre ambiental de Mariana

significados, historicamente definidos, como ocorreu com o espaço e com o território (SAQUET; SILVA, 2008, p. 30).

Para Raffestin (1993), o território seria o resultado de uma ação conduzida por um ator sintagmático em qualquer nível. Ao se apropriar de um espaço, concreta ou abstratamente, o ator "territorializa" o espaço. Assim: “[...] o território (...) é um espaço onde se projetou um trabalho, seja energia e informação, e que, por consequência, revela relações marcadas pelo poder." (RAFFESTIN, 1993, p.50).

A contribuição de Raffestin (1993) permite compreender o território como uma arena onde existe interdependência entre agentes que impõem suas lógicas em distintos momentos, alguns com maior perenidade no tempo e, portanto, no espaço geográfico; e outros que são mais passageiros nessa configuração territorial, sendo suas expressões espaciais mais opacas.

Adicionalmente, Giuseppe Dematteis (2005) entende o território como uma construção social, com desigualdades, com características naturais e relações horizontais e verticais, isto é, significa uma complexa combinação de certas relações territoriais. Segundo o dicionário especializado, Les mots de la Géographie, (BRUNET; FERRAS; THÉRY, 1993), encontram-se referências a dois outros aspectos, concebendo o território como espaço apropriado, com sentimento ou consciência de sua apropriação, reforçando sua dimensão simbólica associada ao ambiente vivido pelos indivíduos, denominado de territorialidade; e compreendido em sua distinção com o conceito de rede; aquele apresentando uma lógica zonal e este último operando numa lógica reticular, orientada pela presença das verticalidades na tessitura de diversas horizontalidades.

Para Andrade (2004), o território estaria vinculado ao espaço de exercício de um poder (domínio ou gestão de uma área), tanto do ponto de vista de um poder público-estatal quanto pelo poder das grandes empresas. Embora subjacente nas definições anteriores, o autor traduz essas relações de poder no/do território para além daquele que o Estado legitimamente exerce e ultrapassa essa perspectiva, sinalizando que o capital e seus arranjos empresariais (de natureza diversificada) também revelam um espaço onde suas lógicas presidem a configuração.

Já para Haesbaert (2006), o território abarca aspectos políticos, político-jurídicos e históricos, a partir da ação do Estado; em termos econômicos, esta atuação se manifesta pela apropriação produtiva dos espaços, em face da divisão territorial do trabalho e da luta de 
ROCHA NETO, J. M.

Os "sem rio": populações desterritorializadas pelo desastre ambiental de Mariana

classes; e culturalmente, identifica-se com aspectos simbólicos - expressas individual ou coletivamente - com o espaço.

Apesar de algumas permanências no entendimento do território, o autor incorpora a dimensão simbólica, que amplia a perspectiva mais complexa das relações de poder em distintas escalas, o que vai revelar os mecanismos para o entendimento desse arranjo socioespacial que recai sobre a área objeto do artigo, a partir das derivações conceituais do território.

Essas derivações são resultantes de contextos complexos, em que o território é objeto de análise de distintos campos do conhecimento, conforme já apontado por Haesbaert (2006), o que se aplica ao caso específico do desastre do rio Doce, considerando que o entendimento de território se dá de forma multidimensional e associa-se aos impactos decorrentes do evento.

Nesse sentido, o debate parece mais apropriado partir do conceito de Território Usado, forjado por Milton Santos, entendido como o conjunto os objetos e ações, expresso no espaço humano e habitado, permeado pelas horizontalidades e verticalidades ligadas por formas de processos sociais e redes. É uma configuração de mediações, sejam elas materiais ou imateriais, que contempla os agentes hegemônicos e hegemonizados, compreendendo-o como uma tessitura de relações complementares, mas também conflitantes (SANTOS, 1996).

Essa perspectiva das horizontalidades na teoria de Milton Santos, possibilita a incorporação das relações sociais forjadas historicamente no território. Embora estas estejam há mais tempo nesse espaço, suas relações são subsumidas pelas verticalidades que se dão a partir das lógicas hegemônicas das corporações capitalistas, notadamente aquelas que operam em larga escala, a exemplo das empresas de mineração. Em outras palavras, seria aquilo que Bourdieu denomina de reapropriação coletiva, que se dá: “[...] sobre os princípios de construção e avaliação de sua própria identidade [do lugar] de que o dominado [população local] abdica em proveito do dominante [corporação empresarial] enquanto aceita ser negado ou negar-se para se fazer reconhecer" (BOURDIEU, 2009, p. 125).

É importante entender que as populações tradicionais ou aquelas que estabeleceram historicamente algum tipo de relação com o rio, por intermédio de seus múltiplos usos, se enraizaram em processo de "territorialização" entendido como o arranjo que se constituiu historicamente ao longo da bacia do rio Doce. São, na realidade, o lugar do habitar, destacado por Claval (2010, p. 44): "Habitar é estar bastante amalgamado com um 
ROCHA NETO, J. M.

Os "sem rio": populações desterritorializadas pelo desastre ambiental de Mariana

grupo e estar inserido bem profundamente num ambiente e com ele se identificar: existe uma hierarquia (...) têm em comum o fato de nascerem da experiência direta de cada um desses indivíduos $[\ldots] "$ ".

Logo, o território aqui é visto como uma totalidade em que distintos usos e lógicas coexistem, nem sempre de forma pacífica, mas que a ele se incorporam as dimensões social, econômica, ambiental, cultural/histórica etc. Assim, a territorialização da bacia do rio Doce foi se constituindo a partir da agregação de distintos atores e atividades que ora se confrontam na disputa pelo território, ora coexistem mesmo que em meio a tensões.

Nesse processo, existem os atores que se incorporam em distintos momentos, sendo a atividade minerária uma atividade histórica nesse espaço, mas com uma particularidade na contemporaneidade, que se dá pela atuação das corporações transnacionais, pois na região, denominada "quadrilátero ferrífero", encontra-se instalado o maior complexo siderúrgico da América Latina, com a presença de empresas como a Arcelor Mittal, Aperam South American, a Vale e a própria Samarco, entre outras.

Apesar de desastre sugerir um processo de desterritorialização, somente algumas de suas características são observadas, pois isso envolveria: o desenraizamento e a desorganização de territórios pela saída ou perda de vínculos identitários da população que constitui um território/territorialidade, ou pela ação externa de comandos estatais ou corporativo-empresariais que introjetam novas lógicas de modernização capitalista e de controles políticos estranhos ao território. A globalização, enquanto processo e discurso do capitalismo financeiro e monopolista, teria uma lógica intensamente desterritorializadora. A desterritorialização associada a catástrofes naturais, guerras e pobreza, cria os aglomerados de exclusão (HAESBAERT, 2006).

Nesse sentido, não se pode fazer uma afirmação peremptória da existência da desterritorialização em face do episódio, considerando que não aconteceu nenhuma diáspora e que isso não se deveu a um projeto de modernização, como ocorreu nos últimos anos com os grandes projetos hidrelétricos. Ademais, não existe associação com catástrofe natural, guerra ou pobreza crônica; mas sim um fato disruptivo que demarca a territorialização impositiva e excludente do Vale do rio Doce. A contribuição de Lameiras aclara essa perspectiva:

Qualquer forma de transição na vida das pessoas causada por algum acontecimento, pressupõe uma mudança que poderá levar à incerteza, exigindo uma capacidade maior ou menor de resiliência dependendo de cada indivíduo, potencializando fatores como o estresse ansiedade. Assim entre desterritorialização in situ e ex situ, 
ROCHA NETO, J. M.

Os "sem rio": populações desterritorializadas pelo desastre ambiental de Mariana

podemos caracterizá-la como sendo, total ou parcial, permanente ou temporária, individual ou coletiva e forçada ou voluntária (LAMEIRAS, 2013, p. 11).

Dessa forma, é necessário entender que a territorialização vem se manifestando historicamente com as mudanças da configuração, mas, sobretudo, pela imposição de lógicas que implicam na disputa pelo território e pelo consequente acesso de uns e pela exclusão de outros. Isso se replica, igualmente, na disputa pelos múltiplos usos do rio Doce para reproduzir determinadas atividades produtivas. A análise de Guedes reforça tal entendimento ao comentar esse novo viés da desterritorialização, que se manifesta pelos: “[...] impactos e efeitos sociais produzidos pelo avanço de certas frentes de acumulação capitalista, incidindo e ameaçando, sobretudo, esses povos e comunidades tradicionais [...]” (GUEDES, 2016, p. 29).

A territorialização, assim como a desterritorialização/reterritorialização, não se manifesta somente pela multiplicidade de usos, sendo sua principal característica a presença de grandes corporações que estabelecem uma organização racional/funcional do espaço, obscurecendo os povos e comunidades tradicionais, nas suas distintas dimensões (culturais, políticas, sociais, ambientais) e promovem alterações significativas no modo de vida dessas populações.

O desastre atingiu todos aqueles que habitam a margem do rio Doce e que dele dependem, em face de um evento de grandes proporções, modifica suas relações territoriais por completo. Para algumas pessoas essas mudanças representam uma ruptura com sua trajetória histórica, notadamente daqueles segmentos que dependiam mais diretamente do rio, e outros veem o fato de forma secundária, mas nem por isso com menos preocupação, pois o corpo d'água agora passa a ser objeto de uma lide, uma vez que novos atores são incorporados passam a pautar a vida cotidiana desses contingentes populacionais, quanto ao uso do rio, e, consequentemente, do território.

\section{Os territórios da mineração}

Não se pode entender o território como um repositório passivo de ações, mas como resultados dos conflitos inerentes à sociedade e acentuados pelos distintos modelos de desenvolvimento, reforçado pelas palavras de Moreira (2006, p. 73) ao analisar que: “A contradição localização-distribuição é então princípio ontológico da constituição do espaço, o 
ROCHA NETO, J. M.

Os "sem rio": populações desterritorializadas pelo desastre ambiental de Mariana

fundamento de seu conceito, a natureza contraditória da formação determinando a natureza intrinsecamente tensa do espaço [...]”'.

No caso do Brasil, apesar da presença histórica da mineração, foi somente nos últimos cinquenta anos que a atividade se viu cooptada pelas grandes corporações e seus mega projetos que causam mudanças a extensas porções do território. Isso se deve a um discurso governamental, que resguarda interesses, da "vocação" do país para o setor em face de suas grandes reservas; mas também pelo movimento de forte internacionalização das empresas de mineração, que além de tornarem-se gigantes, passam também a diversificar sua atuação, seja em setores que ficam a montante ou a jusante da extração.

A proliferação desses grandes projetos, que se apropriam do território, não se dá de forma pacífica, o que fica evidenciado nos dados do Observatório de Conflitos Mineiros da América Latina (OCMAL), uma rede de organizações da sociedade civil que registra os conflitos territoriais relacionados à mineração em larga escala, totalizando 219 conflitos, no ano de 2015, que afetavam 334 comunidades:

Quizá sea más importante señalar que estos conflictos revelan los profundos y negativos impactos que el sector extractivo puede tener en el medioambiente, en las prácticas culturales y en las actividades económicas locales. Además, demuestran que el fracaso de no poder satisfacer las expectativas de los ciudadanos está siendo cada vez más oneroso en términos económicos y políticos tanto para los inversionistas como para los gobiernos (VIEYRA; MASSON, 2015, p. 436).

A análise de atores que impõem suas racionalidades ao espaço geográfico denota processos de desterritorialização/reterritorialização a partir de determinados setores que estabelecem suas lógicas e conformam o território. Nesse sentido, é possível afirmar que, historicamente, o setor de mineração foi um dos que mais atuaram para a desterritorialização de populações, a exemplo dos espaços apropriados pela Companhia Vale do Rio Doce (hoje somente Vale) no estado do Pará, sem contar outras tradicionais áreas como a região objeto do estudo - o quadrilátero ferrífero. Nesse sentido, entender como se processam tais mudanças é esclarecedor:

O projeto minerador muda completamente as relações sociais e as disposições territoriais no espaço. É a partir das mudanças ocorridas que se constituem novas territorialidades, que compõem o entorno da mineração. Tal entorno é formado por um complexo jogo de relações de poder, no qual estão representados atores anteriores e posteriores ao empreendimento. Os novos e velhos atores se interrelacionam, seja para se unirem, quando detêm interesses comuns, ou para confrontarem-se, quando objetivam fins antagônicos. Neste processo de relações sociais, os fluxos de trocas entre os atores sociais são diversos (informações, Revista Cerrados, Montes Claros/MG, v. 18, n. 02, p. 152-182, jul./dez.-2020. 
ROCHA NETO, J. M.

Os "sem rio": populações desterritorializadas pelo desastre ambiental de Mariana

discursos, ideologias, recursos financeiros, recursos naturais, apoios políticos, ações em geral). São através das ações sociais que se constroem as redes conectando os objetos, neste caso, os atores e formando os territórios, por e a partir das relações de poder (WANDERLEY, 2005, p.16470).

Não é possível entender facilmente essas relações, pois elas carregam consigo uma série de interdependências, que tornam essa coexistência quase um pacto, onde as partes mais frágeis (as populações tradicionais) renunciam ao território em benefício das partes mais fortes (as corporações empresariais), que se apropriam e se hegemonizam no uso do território, corroborando para o entendimento de Bordieu (2009) quando analisou a reapropriação coletiva do território.

Assim, o território torna-se refém da atuação da grande corporação, a exemplo do que verificou-se em Mariana. Isso se deve a uma série de fatores: a) elevados investimentos de capital; b) geração de expectativas e/ou criação de grande número de empregos no local; c) atração de grandes contingentes populacionais para a região onde se estabelecerá a empresa, ocasionando uma elevação das taxas de crescimento econômico. Alguns desses aspectos já foram objeto de análise por Corrêa (2001) ao estudar a natureza das grandes corporações na sua integração territorial.

Independentemente do impacto e dos problemas no campo social, o importante, para alguns gestores locais, é o aumento da população constituir-se em um indicador determinante para assegurar a redistribuição de alguns impostos vigentes no país, além dos Royalties pagos pelas empresas pelo uso do território para exploração da atividade. O quadro 1 mostra a magnitude desses valores para os municípios do estado de Minas Gerais.

Quadro 1 - Maiores Arrecadadores Compensação Financeira pela Exploração dos Recursos Minerais 2014 - Estado de Minas Gerais

\begin{tabular}{|l|c|}
\hline Município & Valor arrecadado (R\$) \\
\hline Nova Lima & $106.732 .701,67$ \\
\hline Mariana & $106.059 .924,46$ \\
\hline Itabira & $87.654 .234,10$ \\
\hline Congonhas & $74.044 .400,53$ \\
\hline São Gonçalo do Rio Abaixo & $70.697 .724,69$ \\
\hline Itabirito & $67.068 .307,36$ \\
\hline Brumadinho & $50.001 .650,54$ \\
\hline Ouro Preto & $48.320 .964,70$ \\
\hline Itatiaiauçu & $20.893 .254,36$ \\
\hline Paracatu & $17.116 .298,06$ \\
\hline
\end{tabular}

Fonte: DNPM, 2017. 
ROCHA NETO, J. M.

Os "sem rio": populações desterritorializadas pelo desastre ambiental de Mariana

Adicionalmente, os municípios que absorvem essa população passam a auferir uma maior receita tributária. O melhor exemplo dessa situação é o Fundo de Participação dos Municípios (FPM), em que o coeficiente de participação do município é determinado exclusivamente pelo número de seus habitantes. Quando a população de um município aumenta, o valor da sua cota de rapasses do governo federal também aumenta, conforme disciplina a Lei Complementar n. 91, de 22 de dezembro de 2007.

Apesar disso, os ganhos nem sempre compensam os custos, pois, na maior parte das vezes, o que se percebe é uma assimetria entre os atores que tomam parte desse processo, o que só se revela já no curso de sua implantação, como bem alertam Vieyra e Masson:

Los gobiernos subnacionales son especialmente vulnerables a los problemas relacionados con las capacidades. Aunque su capacidad institucional, que incluye la gestión de los ingresos, suele ser menor que la del nivel nacional, los gobiernos subnacionales tienen la responsabilidad fundamental de gestionar los conflictos sociales y ambientales. Estos son numerosos y costosos (VIEYRA; MASSON, 2015, p. 436).

No Brasil, esses grandes projetos resultaram em estudos que sugeriam uma apropriação menos conflituosa e mais igualitária na participação dos atores envolvidos, que, na maior parte das vezes, não foram considerados em face do modelo de desenvolvimento adotado pelo país, pautado no uso de seus recursos naturais e de retornos rápidos. A titulo de ilustração, recomenda-se consulta aos Estudos de Licitação para Expansão da UHE de Belo Monte, entre as páginas 12 e 18, que apresenta uma matriz de impactos e propostas de solução, algumas delas nunca implementadas, apesar da usina já se encontrar em pleno funcionamento (MINISTÉRIO DE MINAS ENERGIA, 2010).

Sobre tal aspecto é importante salientar os trabalhos de Cunha, Silva e Nunes (2008), que apontam três dimensões dessas intervenções no território: 1) uma relativa às intencionalidades dos atores sociais, que é apresentada na fala dos envolvidos; 2) uma que se refere ao grau de institucionalização dos projetos, percebido no grau de formalização de modelos e estratégias de apropriação dos recursos naturais; e 3) uma dimensão relativa aos diferenciais de legitimação apresentados entre os projetos, referente aos esforços discursivos que dão sentido às intencionalidades. Miranda (2013, p. 155), analisando tais dimensões, destaca: "Os projetos territoriais são fundamentalmente políticos, pois envolvem atores sociais e instituições que podem defender interesses divergentes e são orientados por uma atividade econômica dominante, a qual articula outras atividades, atores sociais e ambientes". 
ROCHA NETO, J. M.

Os "sem rio": populações desterritorializadas pelo desastre ambiental de Mariana

A partir dessa análise, é possível entender como a lógica da mineração se impõe a determinadas frações do território brasileiro e, particularmente, na porção à montante da bacia do rio Doce. Existe um baixo grau de institucionalização quanto a um arranjo participativo, que envolva a sociedade e os atores empresariais sob a mediação do poder público, o que restou, claro, na "surpresa" que foi o episódio de ruptura da barragem, em Mariana.

Trata-se de uma atividade bastante verticalizada, sem espaço para a participação popular, o que revela uma institucionalidade muito baixa quanto à arena de debates, mas muito alta quanto ao caráter corporativo, com anuência do Estado brasileiro, seja pela regulação ou pelas políticas públicas de incentivo ao setor. Esse quadro é sintetizado pelo que Souza Santos (2007) denomina de "fascismo territorial", que obscurece o processo coletivo de discussão do território, que vai no caminho daquilo que Bourdieu (2009) discute ao tratar da reapropriação coletiva do território.

Ademais, as corporações que estão presentes na área do quadrilátero ferrífero demonstram força econômica e política pela organização e pela capacidade de mobilização. Dentre as principais empresas produtoras de bens minerais, em Minas Gerais, estão: Vale, Companhia Siderúrgica Nacional (CSN), Anglo Gold Ashanti, Samarco, Usiminas, Votorantim, Arcelor Mittal, Mineração Curimbaba, V \& M Mineração e Cia. Brasileira de Alumínio (CBA), Kinross, Jaguar Mining, CBMM e Alcoa. Essas companhias financiam campanhas políticas, para o legislativo e executivo, o que lhes asseguram arcos de representação nos poderes constituídos, além de atuarem fortemente por intermédio de instituições associativas, a exemplo do Instituto Brasileiro de Mineração (IBRAM).

Assim, o projeto territorial do alto rio Doce revela um processo de despossessão que se forjou a partir da presença de atividades, as quais modificaram o modo de vida das populações tradicionais, mas, sobretudo, das grandes empresas que atuam na mineração, tornando-o mais território de uns do que de outros. Certamente, esse foi um dos fatores que muito contribuiu para que se instaurasse o ambiente de conflito, quase insuperável no pósdesastre, em face do alcance dos danos, conforme destacado por Passos; Coelho e Dias (2017).

A própria narrativa do poder público se viu no impasse, e tem se mantido entre punir os responsáveis, reparar os danos, assegurar à retomada das atividades da empresa envolvida e reestabelecer as receitas para os governos. Tudo isso em meio a um território que agora se encontra judicializado no seu uso e com uma população reticente quanto ao futuro do 
ROCHA NETO, J. M.

Os "sem rio": populações desterritorializadas pelo desastre ambiental de Mariana

rio, das atividades diretamente relacionadas a ele e daquelas que não dependem exclusivamente, mas foram afetadas.

A trajetória de relações denotou uma interlocução privilegiada com as grandes empresas e quase inexistência de diálogo com as comunidades que habitam a margem do rio. Dessa forma, a legitimidade quase inexiste, pois não há discurso que se mostre adequado a negligência anterior ao evento, quando o poder público não fiscalizou devidamente a ampliação da barragem; nem, tampouco, no pós-desastre que revelou esse descaso e reforça uma percepção de baixa capacidade do Estado brasileiro em coordenar as ações de reparação e punir os responsáveis pelo evento. Esse histórico de omissão do poder público no monitoramento de expansão da atividade já fora apontado por Passos; Coelho e Dias (2017).

Ainda quanto a constituição dos territórios da mineração é importante destacar que, segundo Cunha; Silva e Nunes (2008), os processos de territorialização contemplam as estratégias de produção do espaço, as de reprodução social e as formas de dominação. Assim:

Os processos de territorialização são o resultado das tensões entre os diferentes projetos territoriais e estão relacionados às transformações ocorridas numa figuração social específica, mediante a estruturação, desestruturação e reestruturação das formas de controle dos recursos naturais e da organização do espaço, o que decorre das práticas dos grupos sociais interdependentes (MIRANDA, 2013, p. 155).

Logo, essas frações territoriais vão se especializando e essa "vocação" se reflete na configuração da paisagem, que denota um funcionamento territorial acoplado aos agentes que presidem essa apropriação. No caso específico, como a mineração necessita de grandes extensões para se reproduzir e se realizar enquanto mercadoria, a ocupação do território se dá em larga escala, abarcando um conjunto de recursos naturais e impondo uma reorganização sócio espacial, ou seja:

O projeto minerador muda completamente as relações sociais e as disposições territoriais no espaço. São a partir das mudanças ocorridas que se constituem novas territorialidades, que compõem o entorno da mineração. Tal entorno é formado por um complexo jogo de relações de poder, no qual estão representados atores anteriores e posteriores ao empreendimento. Os novos e velhos atores se interrelacionam, seja para se unirem, quando detêm interesses comuns ou para confrontarem-se quando objetivam fins antagônicos. Neste processo de relações sociais, os fluxos de trocas entre os atores sociais são diversos (informações, discursos, ideologias, recursos financeiros, recursos naturais, apoios políticos, ações em geral). É através das ações sociais que se constroem as redes conectando os objetos, neste caso, os atores e formando os territórios, por e a partir das relações de poder (WANDERLEY, 2005, p. 16470). 
ROCHA NETO, J. M.

Os "sem rio": populações desterritorializadas pelo desastre ambiental de Mariana

Quanto à forma de relação com grupos sociais, uma das estratégias mais utilizadas por essas grandes corporações, e amparada na narrativa do poder público, pelas suas políticas e legislações, é a incorporação da população local à atividade. Com isso se estabelece uma relação complexa, em que os indivíduos são separados entre aqueles que retiram algum benefício da atividade e das empresas e os demais que se tornam meros espectadores. Isso encontra amparo nas palavras de Haesbaert, ao comentar que um dos sentimentos que o território pode provocar é: “[...] medo para quem dele é excluído, de satisfação para aqueles que dele usufruem ou com o qual se identificam" (HAESBAERT, 2006, p. 44).

Dessa forma, o conflito se acirra, pois parte dele é reforçada pelos habitantes do lugar, e com isso a apropriação e o despojo ganham outra face, pois vem sob a máscara (e o discurso) do desenvolvimento e do bem-estar para as comunidades. O exemplo mais emblemático desse processo se deu com o Projeto Grande Carajás, no estado do Pará, que prometeu pagar a dívida externa do país com os recursos vindos da mineração. E no caso específico do vale do rio Doce, o discurso aparece no Plano da Bacia quando destaca a importância da ferrovia que escoa o minério do quadrilátero em direção ao Porto de Tubarão, no estado do Espírito Santo.

A atividade mineradora no Brasil incorpora disputas, conflitos de interesses, alianças de poder, estratégias de acesso e uso do território que se expressam no espaço construído e nas relações sociais. Assim, os territórios da mineração traduzem a histórica relação de subordinação das comunidades locais às estratégias de desenvolvimento de um país semiperiférico, formalizadas nas políticas públicas e leis; que regulam o território e viabilizam sua apropriação. Portanto:

A mineração tende a deixar intocadas as estruturas do subdesenvolvimento, sendo que, muitas vezes, até mesmo aprofunda as contradições do subdesenvolvimento. Isso não significa dizer que a mineração leve necessariamente ao subdesenvolvimento, mas sim que a tendência da mineração é reforçar os traços de concentração de renda e exploração próprias do subdesenvolvimento ou, em outras palavras, desenvolve o subdesenvolvimento (...). Isso facilita a criação de circuitos econômicos exclusivos e, por isso, excludentes das populações locais, principalmente de grupos de baixa renda e minorias étnicas. Sendo assim, os projetos mineradores têm caráter de classe não só por explorarem o fator trabalho na exploração, comercialização e transporte dos minerais, mas também por excluírem da apropriação do excedente econômico o conjunto das classes sociais não detentoras do capital (COELHO, 2015, p. 57).

Dessa forma, a mineração reorganiza, sob sua lógica, extensas áreas, alterando o modo de vida, reconfigurando a paisagem e, sobretudo, tornando mais instável e precária a 
ROCHA NETO, J. M.

Os "sem rio": populações desterritorializadas pelo desastre ambiental de Mariana

relação dos indivíduos com o território, impondo uma lógica de constante incerteza quanto ao futuro. Os reflexos dessa dependência impõem um dilema, no caso específico: a retomada das atividades da mineradora Samarco, no município de Mariana, que representa um expressivo impacto na economia local. De um lado, estão os atingidos pelo desastre que veem suas demandas serem excessivamente postergadas no atendimento, relegando-os a uma situação de insegurança e instabilidade quanto ao futuro; de outro lado, estão os trabalhadores da empresa, tanto nas áreas de extração do minério, como no seu terminal portuário, localizado na cidade de Anchieta, no estado do Espírito Santo.

Existem episódios de preconceito em relação aos moradores do povoado de Bento Rodrigues, manifestados pelas pessoas que ficaram desempregadas em face da desativação das atividades da mineradora, culpando-os pela paralisação da Samarco. Estima-se que a empresa gerava em torno de seis mil empregos diretos na cidade de Mariana e representava 95\% das receitas municipais (FUNDAÇÃO JOÃO PINHEIRO, 2016). Dessa forma, se existem grupos que advogam a permanência da suspensão das atividades, existem também aqueles que defendem sua retomada, argumentando que isso contribui para que os prejuízos do desastre sejam mais intensos ainda.

Não existe opção entre o passado e o projeto de modernização, mas sim uma imposição, que relega ao plano secundário as comunidades tradicionais e seu modo de vida, em detrimento de um pretenso progresso que se faz à custa de prejuízos coletivos e benefícios privados, como o que se verificou no caso de Mariana. Os traços históricos que já vinham sendo substituídos paulatinamente pelo processo de territorialização presidido pelas grandes empresas, nos diversos setores produtivos, são cobertos pela massa de rejeitos advindos da barragem:

\begin{abstract}
Os distritos mais atingidos pelo rompimento da Barragem de Fundão possuíam cerca de 300 anos de história. Nesse espectro temporal a presença da Samarco é efêmera, mas sua mineração predatória conseguiu dar fim à história local de mineração. Sucessivas gerações que ali viveram constituíram a identidade desses lugares que vieram da agricultura familiar e da mineração manual durante séculos. As primeiras capelas de Bento Rodrigues e Paracatu foram construídas por volta de 1718 e 1730, respectivamente. Foram reconhecidas por seu valor histórico e cultural muito antes do desastre. Estudos realizados nessas localidades também haviam identificado sítios arqueológicos que foram arrasados pela lama (ARCURI; LAIA; SUNER, 2016, p. 216).
\end{abstract}

O prejuízo ao patrimônio histórico de Bento Rodrigues, notadamente a capela de São Bento, fica demonstrado na fotografia do assoalho, que expressa a intensidade da Revista Cerrados, Montes Claros/MG, v. 18, n. 02, p. 152-182, jul./dez.-2020. 
ROCHA NETO, J. M.

Os "sem rio": populações desterritorializadas pelo desastre ambiental de Mariana

destruição causada pela massa de rejeitos, reforçando as palavras de Becker ao dizer que: “[...] as fotografias ganham sentido a partir do seu contexto (...) e por discussões em curso em torno delas e dos temas que tratam[...]" (BECKER, 2009, p. 190).

Fotografia 1 - Visão do assoalho da capela de São Bento no povoado de Bento Rodrigues

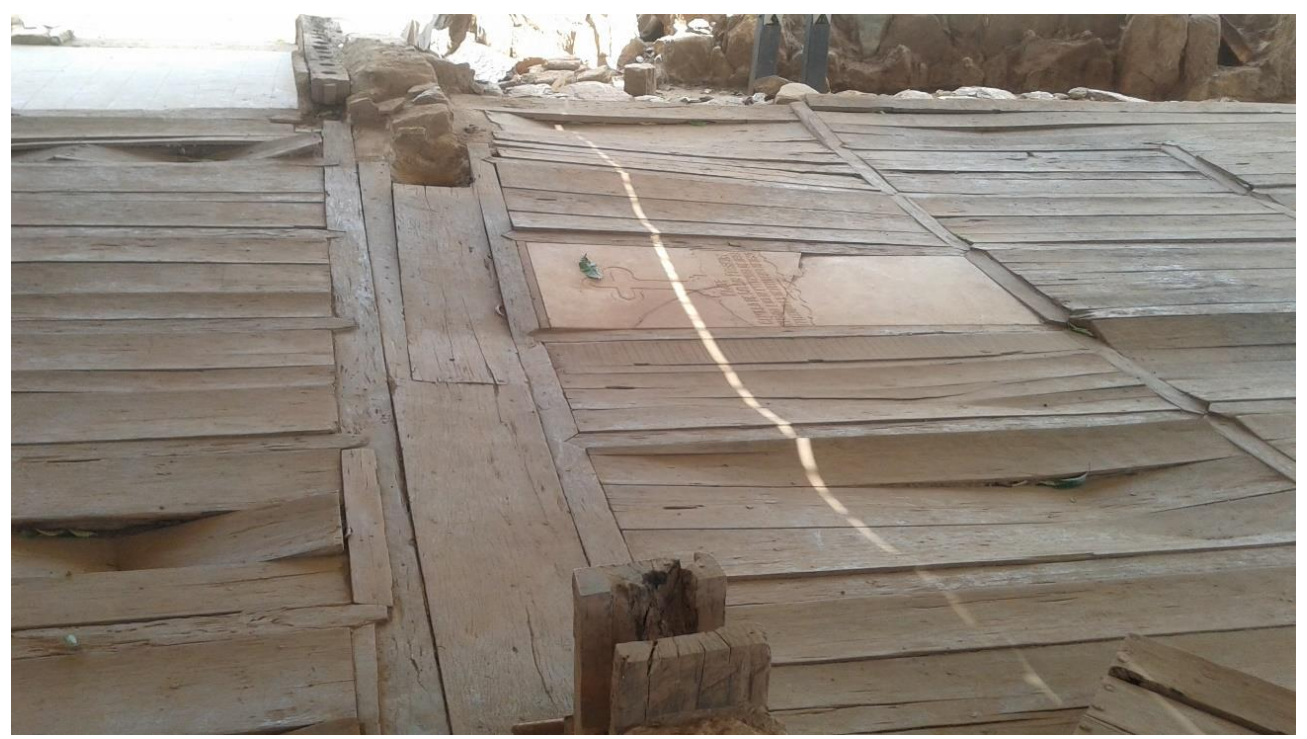

Fonte: o autor, 2016.

Assim como a capela que possuía significação para coletividade, desapareceram as histórias dos sujeitos que habitavam a localidade. Há, portanto, prejuízos de natureza material, mas sobretudo, perdas emocionais, em um claro processo de despojo do território e da vida privada.

\section{O episódio: a irrupção do despojo territorial}

Em 5 de novembro de 2015, o rompimento da barragem de Fundão, em Mariana, liberou um volume de 34 milhões de $\mathrm{m}^{3}$ de rejeitos, causou a morte de 19 pessoas e afetou uma população superior a 420 mil pessoas que se distribuem ao longo de 660 quilômetros do rio Doce, coroando, o processo de desterritorialização já em curso, em um desastre ambiental em escala jamais vista no Brasil (AGÊNCIA NACIONAL DE ÁGUAS, 2016).

Segundo o governo de Minas Gerais, só naquele estado os prejuízos econômicos imediatos do desastre foram estimados em pelo menos R $\$ 1,2$ bilhão, sendo que mais de 320 mil pessoas foram - de alguma maneira - afetadas pelo desastre (Minas Gerais, 2016). As 
ROCHA NETO, J. M.

Os "sem rio": populações desterritorializadas pelo desastre ambiental de Mariana

multas e sanções pecuniárias aplicadas e estimativas parciais sobre os danos estimam as perdas econômicas, em consequência do episódio, em R\$26,2 bilhões de reais (TERRA BRASIS RESEGUROS, 2016).

O desastre de barragem de Bento Rodrigues é um ponto de aceleração no processo de desterritorialização que já vinha se desenhando pelas transformações históricas e a ocupação das margens do rio Doce por atividades econômicas diversas que se destinavam ao suporte da economia urbana/industrial. Portanto:

A tragédia provocada pela Samarco sobre o Rio Doce e suas comunidades expõe o ápice desse conflito entre as matrizes de racionalidade e as práticas de territorialidade dos sujeitos envolvidos, revelando a incompatibilidade entre as duas visões de mundo (...). De um lado, a visão e prática da mineradora, orientada pela matriz de racionalidade desenvolvimentista capitalista, que limita a natureza à ideia de recurso, onde solo e subsolo são exauridos para a extração de minérios destinados à exportação (para posterior importação de eletrônicos), e os rejeitos da atividade são depositados nos cursos d'água, inviabilizando quaisquer outros usos (FERREIRA, 2016, p. 273).

Da perspectiva da intensidade do desastre, em tese, a população mais afetada seria aquela dos distritos de Bento Rodrigues e Paracatu de Baixo, nas proximidades de Mariana. A primeira povoação teve seus 600 moradores afetados e mais de 200 imóveis comprometidos pelo rio de rejeitos. No entanto, por se tratar de um curso de água que se estende por dois estados do Brasil e que seus usos são múltiplos, os impactos são igualmente difusos e complexos, se estendendo por centenas de quilômetros. O fragmento textual denota a magnitude do desastre:

Ao longo de semanas ficamos todos perplexos com a escala do desastre causado pelo rompimento da barragem do Fundão: um mar de lama rio abaixo, levando tudo o que encontrava no caminho, desde pessoas, plantações, bois, cavalos, porcos e cabritos até lixo, entulho e tudo mais existente no seu trajeto alterado pelos milhões de metros cúbicos de lama! Muito triste ver peixes se debatendo, tentando respirar e cada vez mais sendo enterrados nesta lama! Pequenas centrais hidrelétricas tiveram sua barragem de água substituída por rejeito e lama. Também desapareceram moluscos, plantas aquáticas, vegetação ribeirinha e até o limo das pedras que serve de alimento para os animais aquáticos. A paisagem geral ao longo do rio que transbordava era do tipo "lunar" mais evidente ainda pelo brilho escuro do minério de ferro em suspensão e que se depositava instantaneamente, tamanha sua concentração na água. Na medida em que se depositava e secava ia cobrindo o leito, as margens, as áreas do entorno (BARBOSA; MAIA-BARBOSA; NASCIMENTO et al., 2015, p. 164).

Em algumas horas, o território já marcado por mudanças se desfaz na sua plenitude. Comunidades tradicionais e cidades centenárias, além de outras populações que 
ROCHA NETO, J. M.

Os "sem rio": populações desterritorializadas pelo desastre ambiental de Mariana

habitam a margem do rio são impelidas a estabelecer com ele uma nova relação, refazendo sua imagem e seus laços afetivos, determinada pela restrição ao consumo e pela insegurança no seu uso.

A dimensão do desastre é diretamente proporcional aos efeitos no tempo e no espaço que ele provocou (e provocará no futuro), evidenciando que as relações de dependência existentes com o curso d'água estão comprometidas por anos a considerar os impactos destacados pela Agência Nacional de Águas (2016): a) interrupção do abastecimento de água em função da degradação da qualidade da água nos rios afetados; b) prejuízos à agricultura (irrigação); c) prejuízos à indústria e demais atividades econômicas que dependem da qualidade da água dos corpos hídricos atingidos; d) prejuízos à produção de energia nas hidrelétricas; e) comprometimento da pesca em toda a extensão do rio e na transição com o ambiente marinho; f) comprometimento do turismo, sobretudo na região do estuário do rio Doce; g) destruição de áreas de preservação permanente nos trechos de cabeceira; h) assoreamento dos corpos hídricos; i) alterações morfológicas dos corpos hídricos atingidos; j) mortandade de peixes e de outros organismos aquáticos; e k) perturbações do equilíbrio dos ecossistemas aquáticos.

Nesse contexto, despontam novos atores e o corpo d'água passa a ser objeto de um litígio onde as comunidades tradicionais são apenas espectadores passivos frente a uma complexa arena de disputas. A velocidade das reparações é diametralmente oposta aos efeitos do desastre, considerando que a fluidez do corpo de água para espalhar os rejeitos em nada se assemelha a capacidade de resposta do poder público.

Embora as ações mitigatórias emergenciais tenham ficado a cargo do poder público, em face da urgência de resposta, a execução das ações de reparação em médio e longo prazo ficaram sob a responsabilidade da Fundação Renova, instituída pelas empresas controladoras da SAMARCO, Vale e BHP Billinton.

Ainda existem outros atores centrais nesse processo que são o Ministério Público (federal e dos estados); a Defensoria Pública (federal e dos estados) e o poder judiciário que seria a instância de arbitragem do litígio. No entanto, a postura dessas instituições e as decisões judiciais colocam em dúvida a celeridade e intenção de fazer as reparações aos atingidos, considerando que algumas das ações propostas pelo Ministério Público estão suspensas. 
ROCHA NETO, J. M.

Os "sem rio": populações desterritorializadas pelo desastre ambiental de Mariana

Assim, haveria um conjunto de atores centrais que poderia ser separado em dois agrupamentos: a) o primeiro que discute na esfera judicial (criminal e cível) os efeitos do desastre, para posteriormente penalizar seus causadores; b) o segundo que atua para reparar os danos decorrentes do episódio. No entanto, não existe formalmente nenhuma instância que incorpore a participação da sociedade civil, o que vem revelando a fragilidade desses atores, levando a empresa e a Fundação Renova a transacionar acordos extrajudiciais, que ainda não se sabe se promovem de fato as reparações necessárias às comunidades.

Adicionalmente, o conjunto de iniciativas desse complexo arranjo de governança, apresenta descompasso na resolução de algumas questões ainda em aberto, sobretudo aquelas que asseguram a qualidade da água para abastecimento das populações, além de encaminhar ações que possibilitem a retomada de atividades produtivas dependentes diretamente do rio, tais como agricultura, pesca e turismo.

Essa demora em oferecer respostas e soluções leva os moradores a um sentimento de abandono e desesperança que marca episódios dessa natureza conforme já destacado no fragmento textual:

[...] o vagar nas providências burocráticas de reconhecimento da emergência nos níveis superiores de governo, é um indício preocupante de indiferença pública ao quadro agudo de desproteção de direitos dos afetados. A letargia burocrática decorrente de um misto de insuficiência de quadros, incapacidade técnica e rotinas administrativas lentas, cuja morosidade é aceita socialmente, é dissonante de um ideário de atendimento pleno nas emergências, visando à ideia de normalização das rotinas do lugar (VALENCIO; SIENA; MARCHEZINI, 2011, p. 35).

Logo, existe uma desproporção entre aquilo que vem sendo feito e entregue aos atingidos, pelo poder público, nos três níveis, bem como pela Fundação Renova, e ainda não se encontrou um formato de "escuta" da população de forma sistematizada, havendo uma fragmentação nesse processo e, consequentemente, nas respostas, que continuam se mostrando excessivamente demoradas.

\section{A vocalização dos "sem rio" e as imagens da territorialidade pós-desastre}

Por fim, a abordagem da questão não poderia ser completada, sem uma aproximação com os atingidos pelo desastre, na forma de entrevistas. Para tanto, a análise do discurso foi um recurso relevante, com a finalidade de captar percepções, pois: “[...] refere-se 
ROCHA NETO, J. M.

Os "sem rio": populações desterritorializadas pelo desastre ambiental de Mariana

a um conjunto de enunciados produzidos no seio da história, dentro de uma referência espacial e, sobretudo, de um conjunto complexo de saber e poder" (MARTINS; CLEPS JÚNIOR, 2013, p. 69), e assim possibilitar uma triangulação com o debate teórico.

Nas ocasiões, foram também feitos registros fotográficos dos lugares e pessoas atingidos pelo desastre, considerando que L'Estoile e Sigaud (2006) apontam que fotografias, como recursos visuais, são uma ponte entre o pesquisador e os pesquisados. No entanto, optou-se pela preservação da imagem dos indivíduos, embora se reconheça que tais registros vão além da mirada inicial, permitindo interpretações sobre os sentimentos. Dessa forma, as imagens trazidas no curso do artigo são aquelas feitas nas localidades atingidas pelo desastre e que se mostraram marcantes para o imaginário dos habitantes do vale do rio Doce, bem como ficaram registradas pela grande mídia e internalizadas na sociedade brasileira.

A aproximação com os atingidos pelo desastre é sempre um processo delicado, pois envolve uma enorme carga de apatia quanto a resolução de seus problemas, criando um ambiente tensionado, mas, também, são esses sentimentos que permitem extrair da população algumas falas que norteiam esta análise e demonstram a necessidade de modificar a relação entre o poder público e sociedade civil, considerando que os efeitos do desastre ainda se prolongarão por muitos anos, quiçá até por décadas.

Aqui os sujeitos serão desidentificados, pois suas narrativas resultam de um processo de consulta sistematizada, mas não oficial, que buscou entender a extensão dos danos causados pelo desastre e a percepção da população atingida quanto a capacidade de resolução e resposta, por parte do poder público e da Fundação Renova.

Um dos participantes demonstrou preocupação com as ações emergenciais de apoio à população local, externando uma impressão pessoal: “[...] que as ações dos agentes envolvidos estão muito mais adiantadas nos aglomerados urbanos ao longo do Rio Doce e as comunidades de Regência e Povoação onde as ações deveriam chegar, ainda não chegaram na velocidade necessária [...]", citando inclusive o esgotamento sanitário e demais ações previstas no Termo de Ajustamento de Conduta - TAC.

Vale ressaltar que a questão de esgotamento sanitário não possui relação com o desastre, mas foi uma das iniciativas que as prefeituras demandaram, no âmbito do TAC, substituindo a política federal de saneamento, que historicamente vem encontrando dificuldades orçamentárias na sua implementação. Nesse sentido, verifica-se que a aplicação 
ROCHA NETO, J. M.

Os "sem rio": populações desterritorializadas pelo desastre ambiental de Mariana

dos recursos a serem dispendidos pela Fundação Renova, extrapola a reparação de danos decorrentes do desastre.

Passados quatro anos do desastre, é fato notório que as ações ainda são demoradas nas suas respostas, como já destacado, mas também ficou evidente que as maiores cidades receberam mais atenção do poder público, nos dois estados, em face das pressões exercidas pelos grandes contingentes populacionais. Tal fato reforçou nos atingidos uma percepção de tratamento diferenciado e negligência no atendimento de pequenas comunidades e das populações rurais que se encontram difusas pelo território. Essa situação apenas acentua um processo de desconfiança que já se delineava anteriormente e foi relatado por Viana (2012) ao apontar que em Bento Rodrigues, aproximadamente 64\% dos moradores já temia a presença das empresas de mineração, inclusive em relação a propriedade dos seus imóveis.

Uma liderança local pontuou que os atingidos vêm se reunindo com inúmeros interlocutores, a fim de repassar suas necessidades e aguardando as devolutivas, que neste tempo aconteceram constantes substituições, houve a troca de governo e equipes técnicas dos órgãos envolvidos neste processo, e que a grande preocupação é a perda que todas essas mudanças trazem ao processo. No atual governo, as instâncias de diálogo com a sociedade civil sofreram um revés com a edição do Decreto n. 9.759, de 11 de abril de 2019, que revogou diversos colegiados instituídos por Decretos ou Portarias, inclusive o Comitê Interfederativo - CIF que atuava no planejamento de ações reparadoras.

Os laços de confiança são relevantes em qualquer relação, sobretudo, quando se dão em meio a uma situação conflituosa, como é o caso. As mudanças ocorridas no governo brasileiro, pois menos de seis meses depois do desastre ocorreu o impeachment da Presidente Dilma Rousseff, ocasionaram mudanças na administração pública e, consequentemente, na interlocução com a população atingida. Nesse sentido, as respostas tiveram atraso, em face da apropriação do assunto pelos novos gestores, bem como de modificações ocorridas na estrutura da Fundação Renova. Esses são fatores que acirram a tensão e aprofundam a apatia dos atingidos, quando se observa a secundarização de suas necessidades urgentes.

Um comerciante local destacou não possuir mais condições financeiras e nem psicológicas de atender aos clientes, que vários comerciantes fecharam as portas dos seus estabelecimentos, o que refletiu na economia doméstica levando alguns deles a inadimplir com escolas e faculdades dos filhos, destacando que no passado: “[...] nunca atrasaram uma 
ROCHA NETO, J. M.

Os "sem rio": populações desterritorializadas pelo desastre ambiental de Mariana

mensalidade e que hoje apresentam de três, quatro a cinco, mensalidades atrasadas". E complementou que nem sabia se manteria os filhos matriculados no ano seguinte.

Destacou ainda que, como comerciante, sempre esteve com seus compromissos financeiros em dia e que agora tem dívidas que ultrapassam 60 mil reais. O mesmo participante destacou que as promessas de indenizações estavam previstas para fevereiro de 2016 e depois passaram para julho do mesmo ano e que os socorros oferecidos, além de atrasados, não cobrem todos os aspectos dos prejuízos sofridos, que tem morador com contas de energia atrasadas por três ou quatro meses.

O sentimento de insegurança quanto ao futuro das famílias gerou uma série de problemas emocionais, segundo relatos dos órgãos de saúde estaduais. O fato de suas vidas financeiras dependerem de terceiros, envoltos na burocracia, tem afetado a população que dependia de alguma forma do rio para sobreviver. Em estudo realizado sobre os efeitos na saúde mental dos atingidos pelo rompimento da barragem de Fundão, Freitas et. al. (2019, p. 1) destacaram que:

Para se compreender esse desastre e seu significado no âmbito da Saúde Pública, há de se considerar três consequências, combinadas ou não entre si: (i) interrupção do funcionamento normal do cotidiano local ou regional, envolvendo perdas e prejuízos (materiais e culturais, econômicos e ambientais), bem como ampliação dos riscos, doenças e óbitos; (ii) sobrecarga das capacidades institucionais locais ou estaduais, superior a sua capacidade de atuação com uso de seus próprios recursos; e (iii) alteração dos contextos de produção de riscos e doenças, entre características preexistentes e novas, criados após o evento, resultando em uma sobreposição de condições de risco e danos ambientais e humanos nos territórios e populações afetados, possíveis de se prolongar por meses e anos.

O problema fica bastante agravado nas comunidades que tinham como fonte de renda predominante a agricultura, a pesca e o turismo. No caso dos dois últimos, isso está relacionado, sobretudo, a porção litorânea do estado do Espírito Santo, onde se localiza a foz do rio Doce e existem vilarejos que sobreviviam dessas duas atividades, a exemplo de Regência.

Uma professora complementou a fala do interlocutor dizendo que as localidades de Regência e Povoação - ES têm as mesmas características dos atingidos em Mariana-MG, com ribeirinhos, pescadores, comunidades tradicionais, mas que a aparência é de que a urgência e os direitos não são os mesmos. A própria cobertura da imprensa revelou uma centralidade de Mariana, em face de sua proximidade do local do desastre, reforçada no linguajar popular que denomina até hoje o episódio como o "desastre de Mariana" ou o Revista Cerrados, Montes Claros/MG, v. 18, n. 02, p. 152-182, jul./dez.-2020. 
ROCHA NETO, J. M.

Os "sem rio": populações desterritorializadas pelo desastre ambiental de Mariana

“desastre da Samarco", obscurecendo até o povoado de Bento Rodrigues, o rio Doce e outras localidades que estão no seu curso. Tal fato, vem revelando a percepção que as comunidades mineiras possuem um tratamento diferenciado e mais célere nas suas demandas, que as do estado do Espírito Santo.

A professora ressaltou que para a população, a Samarco (Fundação Renova) está gastando muito dinheiro em programas e contratação de pessoal, que possui canais de comunicação que não se mostram efetivos no diálogo com os atingidos e que tais recursos deveriam ser destinados a ações mais efetivas. No entanto, é necessário destacar que os Programas previstos no TAC necessitam de acompanhamento, por parte da Fundação e do seu Conselho Curador, que estão sob o crivo legal e fiscalização do Ministério Público, para tanto, possuir um quadro de colaboradores é imprescindível. Porém, ainda deve existir uma preocupação de todos os órgãos, notadamente aqueles que realizam fiscalização e controle, quanto aos excessos praticados, seja na remuneração desses profissionais, como também na quantidade ideal para atuar na implementação dos Programas.

Por fim, a professora afirmou entender que: “[...] o país não estava preparado para tragédia de tais proporções, mas se o país não estava, a comunidade também não, com o agravante que a comunidade é a parte mais vulnerável de toda a situação". De fato, essa narrativa evidencia a surpresa do país, que vivencia o desastre pela cobertura da mídia, mas não é afetado pelo episódio; e ao mesmo tempo o drama dos atingidos pelo desastre, que sobrevivem na incerteza, sofrendo de perto os efeitos do desastre.

A liderança prosseguiu enfatizando que o impacto social é muito maior do que o ambiental e que o governo não fez muita coisa para ajudá-los, uma vez que o desastre é um fato e: “[...] agora temos que pensar em como conviver com ele e buscar soluções alternativas de viabilização da sustentabilidade local, de reorganização social, pois estamos falando de gente". Apesar de toda apatia e descrédito que toma conta de grande parte dos atingidos, existem lideranças que desejam encontrar soluções para a superação da crise instaurada. E complementou: "o que não pode acontecer é as pessoas se tornarem dependentes de uma pensão mensal [auxílios da Fundação Renova]”.

Destacou ainda a liderança que as ações previstas nos programas do TAC, devem e vão contribuir muito para a recuperação da qualidade de vida da comunidade, mas após um ano [agora quatro] ainda não chegaram e indagou sobre a espera, lembrando que o tempo é um fator relativo. Ou seja, para os atingidos tudo é urgente, pois suas vidas se desestruturaram 
ROCHA NETO, J. M.

Os "sem rio": populações desterritorializadas pelo desastre ambiental de Mariana

completamente, já para os atores responsáveis pelas ações de reparação (CIF e Fundação Renova), o tempo é determinado pelos procedimentos burocráticos. A liderança alertou: “[...] a previsão de seis meses, pode parecer pouco tempo para alguns, mas para os que já estão na expectativa e nessa situação há um ano, passando necessidades, humilhações e agressões todos os dias, e ainda sendo acusados pelos demais comunitários de estarem vendidos às empresas, precisando até mesmo, se trancar dentro de suas casas".

Esse aspecto só é percebido pelos que habitam as áreas afetadas pelo desastre e foi narrado pela liderança ao comentar que há uma desestruturação social das comunidades com ocorrências de casas invadidas, brigas entre vizinhos e familiares, em face do tratamento diferenciado que a Fundação Renova vem dando nos auxílios, seja na tempestividade e mesmo nos critérios para concessão, o que se refletiu na sua fala: "Nós perdemos nossos laços familiares, perdemos aquele sentimento gostoso de comunidade, perdemos o costume de sentar, sorrir e dar um bom dia, hoje em dia, nós só escutamos, quando chega o meu cartão, porque meu cartão não chegou? Os muros das casas estão aumentando porque os vizinhos não se suportam mais".

A mesma liderança pontuou ainda que os problemas ambientais que acometiam o rio eram de conhecimento amplo, mas que antes do desastre essas populações ainda tinham de onde tirar seu sustento. Ou seja, os problemas ambientais enfrentados pelo rio já eram percebidos pelas populações cotidianamente, quadro que foi agravado pelo episódio, e conclui: "Um ano de necessidades, um ano de portas fechadas, um ano de mensalidades escolares atrasadas, um ano de pesca prejudicada, um ano de pousadas vazias, um ano de água contaminada". É uma fala que revela a extensão do desastre para aqueles que viviam do rio Doce.

O representante da associação dos pescadores falou que está recebendo o auxílio da empresa que gira em torno de $\mathrm{R} \$ 1.200,00$, mas que em plena atividade tinha mês que tirava entre $\mathrm{R} \$ 7.000,00$ e $\mathrm{R} \$ 8.000,00 /$ mês e que ainda existe o problema da ociosidade dos equipamentos de pesca e de refrigeração do pescado, gerando depreciação de toda a estrutura, por conta da proibição da pesca na região.

Ressalte-se que a determinação veio da Marinha do Brasil, orientada pelos primeiros estudos realizados pelos órgãos ambientais, os quais detectaram alto grau de turbidez das águas do rio e na sua foz, bem como de índices elevados de rejeitos de minério em suspensão, o que poderia comprometer o consumo do pescado. Há de se chamar atenção 
ROCHA NETO, J. M.

Os "sem rio": populações desterritorializadas pelo desastre ambiental de Mariana

para uma situação que fragiliza sobremaneira as populações tradicionais, notadamente os pescadores, seu alto índice de analfabetismo, que dificultou a mobilização da classe na defesa de seus direitos e a liderança da classe apela: "Estamos falando de vidas, água é vida. O que nós temos é isso aqui [com uma garrafa de água na mão], nós não buscamos riquezas, buscamos somente nossa vida de volta”. É um reclame pelo resgate do passado, que já não pode retornar, mas também um alerta para a necessidade de se cuidar do recurso elementar para a vida social e econômica do território, a água.

Essa inconstância quanto à qualidade do pescado, em face de distintas metodologias adotadas pelos órgãos ambientais, é um dos maiores fatores de insegurança das populações ribeirinhas e sempre destacada, conforme se verificou na fala do representante da associação comercial que questionou quanto à falta de informações claras sobre análises a respeito da contaminação do pescado.

De forma geral, os representantes alertaram que a comunidade teve sua dieta radicalmente alterada, pois antes consumiam pescado e outros alimentos produzidos na região e que hoje, têm de lançar mão de uma dieta com predominância de processados e que a preocupação com a saúde dos moradores é grande, em face da abrupta mudança.

A representante da associação de moradores chamou a atenção para o fato de muitas crianças, idosos e demais membros da comunidade adoecerem, apresentando quadros de dores abdominais, coceiras, dormências, entre outras enfermidades, que estão relacionando essas ocorrências à água e alimentação, possivelmente contaminada, e a ausência de estudos e laudos conclusivos quanto ao nível de contaminação dos recursos, o que só faz aumentar a desconfiança e a rejeição da população.

Uma liderança local, indagou aos pesquisadores: "Vocês notaram alguma coisa na feição dos comunitários aqui presentes?", sendo-lhe respondido que se percebia um ar de apreensão em todos. Diante da resposta, o participante continuou sua fala dizendo não haver o mínimo de alegria na feição dos mesmos, que desde a ocorrência do desastre: "nossa comunidade não consegue mais sorrir”. Trata-se de uma manifestação que sintetiza todas as demais escutas e está associada aquilo que a psicologia ambiental trata como Estima de Lugar, que pode ser potencializadora ou despotencializadora: “[...] significa dizer que mesmo o sujeito destacando aspectos desagradáveis do ambiente (...) sinta-se desvinculado do ambiente por considerá-lo despotencializador" (AUGUSTO; FEITOSA; BONFIM, 2016, p. $151)$. 
ROCHA NETO, J. M.

Os "sem rio": populações desterritorializadas pelo desastre ambiental de Mariana

Há, portanto, um ambiente de instabilidade e insegurança, individual e coletiva, que tomou conta das comunidades e reforça um aspecto associado as paisagens do medo de Tuan, quando enfatiza os efeitos do desastre como uma força hostil, que causa aversão, pois a pessoa não se reconhece ali e não percebe a vida socialmente compartilhada (TUAN, 2005). Essa paisagem de incerteza e improviso se revela na imagem seguinte.

Fotografia 2 - Panorâmica do sítio onde se localizava o povoado de Bento Rodrigues

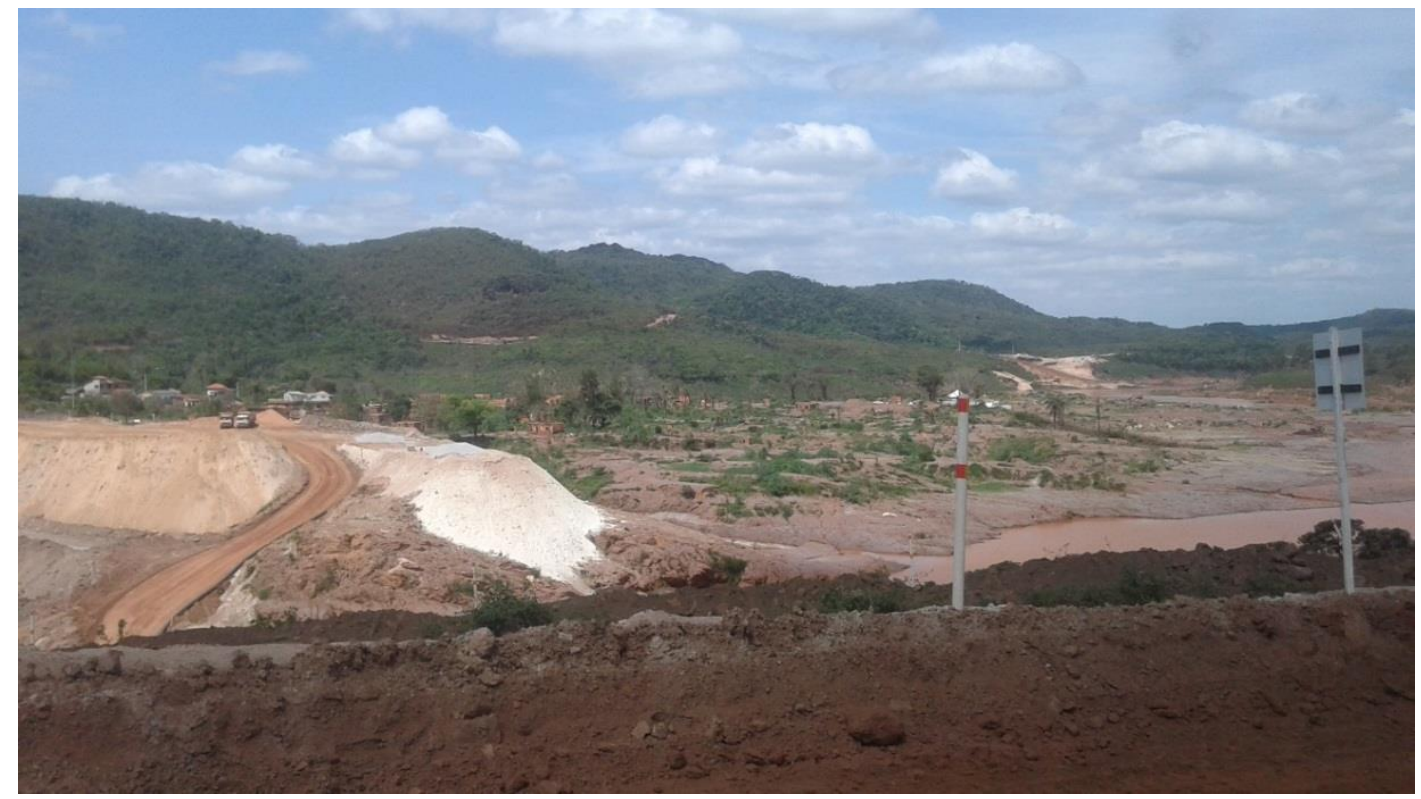

Fonte: o autor, 2016.

A mesma liderança reclamou o apoio do poder público para que os moradores possam voltar a sorrir e disse que é necessário: “[...] levantar a cabeça e buscar mudar a sua realidade atual, mostrando aos turistas que existem atrações, como lagoas, trilhas, praias para que possam mostrar aos praticantes do surf, mas só com o apoio dos agentes e da comunidade não é possível mudar a realidade". A percepção do entrevistado denota a importância de uma atuação de múltiplos atores na superação dos problemas decorrentes do desastre, o que implica em: "[...] ampla repactuação de forças antagônicas, bem como contratualização dos compromissos" (BRANDÃO, 2008, p. 150).

Por fim, se percebeu um ar de esperança nos participantes quando destacam as iniciativas independentes na busca de saídas para a crise, seja na busca de parcerias ou no encontro de alternativas para retomada das atividades econômicas, assegurando a geração de emprego e renda, tais como trilhas agroecológicas; plantações de cacau e beneficiamento por Revista Cerrados, Montes Claros/MG, v. 18, n. 02, p. 152-182, jul./dez.-2020. 
ROCHA NETO, J. M.

Os "sem rio": populações desterritorializadas pelo desastre ambiental de Mariana

intermédio de pequenas indústrias; e mesmo o turismo que poderia ser gerado em face do desastre que ainda desperta a curiosidade de muitas pessoas. Apesar de todas as adversidades a população parece não ter desistido de reconstruir uma nova relação com o território, a partir das restrições que ainda lhe são impostas, ou aquilo que se denominará de reterritorialização limitada.

Entende-se que mesmo que os programas, indenizações e compensações cheguem, nada vai recuperar todos os flagelos e as consequências psicológicas e sociais a que foram submetidas a população que dependia do rio Doce de alguma forma e que o sentimento de desaparecimento do território e da história que ele carrega consigo se expressa na fala de uma moradora ao dizer: "Não, Bento [Rodrigues] acabou. Bento [Rodrigues] foi um lugar que existiu e não existe mais. Virou fantasma, não existe mais nada lá além de umas seis casas de sobra. Mas acabou. Foi uma catástrofe". Esse fragmento, conjuntamente com a imagem seguinte, rememora a fala de Claval (2010) sobre o habitar, bem como permite compreender a força da desterritorialização promovida pelo desastre.

Fotografia 3 - Casa atingida pela lama da Barragem de Fundão

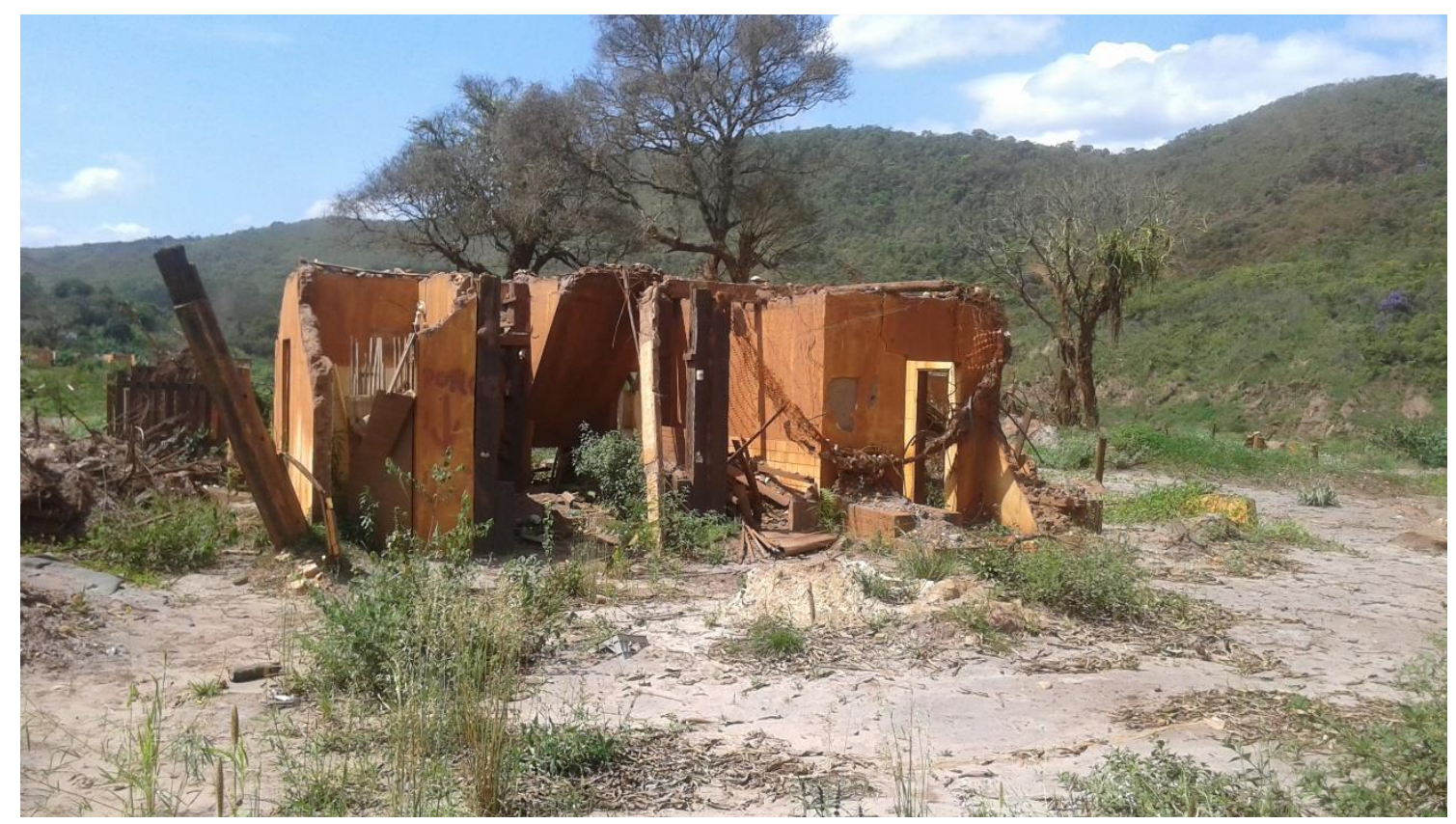

Fonte: o autor, 2016.

Dessa forma, a compreensão do processo ocorrido, denota um sentimento que se situa entre o abandono, a indignação e uma certa resignação, considerando que a vida desses indivíduos parece ter escapado às suas mãos, sinalizando para um futuro cheio de incertezas, 
ROCHA NETO, J. M.

Os "sem rio": populações desterritorializadas pelo desastre ambiental de Mariana

mas que terá, por muitos anos, nas suas vidas e no imaginário coletivo, a presença da lama e do desenraizamento territorial.

\section{CONSIDERAÇÕES FINAIS}

A partir do que foi discutido, o artigo sugere uma nova territorialização que cristaliza a histórica disputa pelo uso do território e, consequentemente, do rio na forma da judicialização territorial, decorrente do desastre. Para as populações ribeirinhas (rurais e urbanas) isso resulta em um ambiente de tensionamento e forte instabilidade na sua vida cotidiana; para os atores institucionais envolvidos no planejamento de ações e na reparação dos danos resulta em um cenário jamais visto no país, que nunca teve a cultura da prevenção de riscos como um dos focos das políticas públicas; e para a empresa envolvida constitui-se em um episódio que a inobservância de normas e o desejo de maximizar lucros, aliado a leniência do poder público, resultou em altos prejuízos.

Adicionalmente, o processo de escuta realizado se deu de forma excessivamente desarticulada, o que fracionou a vida e os territórios em temas, como se eles não guardassem relação entre si. Dessa forma, as ações de reparação tem sido objeto de críticas quanto a sua efetividade e vem se mostrando como um fator de acirramento das tensões entre os atores envolvidos.

A escuta dos atingidos e os registros fotográficos das áreas impactadas pelo desastre corroboram para sentimentos paradoxais dos atingidos, que ora expressam profunda apatia e descrença na resolução de seus problemas, mas também externam uma visão de futuro que sinaliza para o resgate de suas vidas e, portanto, da reconstituição do território.

A complexidade do episódio é tamanha que diversos campos do conhecimento se mobilizaram para estudá-lo, como ficou demonstrado em face da revisão de literatura feita pelo artigo, mas sempre com um norte territorial. Essa perspectiva multidisciplinar constituise em uma imposição para se analisar episódios dessa natureza, dada a sua complexidade e extensão no tempo e no espaço geográfico.

Existiriam outras questões ainda por responder, a partir do entendimento que as relações entre atores não devem necessariamente ser de subordinação e de concessão da totalidade do território para as grandes corporações, ou aquilo que poderíamos denominar de “desastres consentidos”. Alternativamente, pode-se pensar a adoção de uma perspectiva Revista Cerrados, Montes Claros/MG, v. 18, n. 02, p. 152-182, jul./dez.-2020. 
ROCHA NETO, J. M.

Os "sem rio": populações desterritorializadas pelo desastre ambiental de Mariana

relacional, em que os usos do território coexistam, sem que necessariamente sejam apropriados exclusivamente pelos atores hegemônicos.

Por fim, o perigo que se coloca no momento é o que denominamos de “obscurecimento do desastre da barragem do Fundão", em face dos novos grandes acidentes ambientais ocorridos no país, a exemplo de Brumadinho e do derramamento de óleo no litoral.

Essas ocorrências só reforçam a postura leniente, que associou o modelo de desenvolvimento brasileiro de apropriação dos recursos naturais e de permissividade do poder público em relação a atividades potencialmente danosas ao meio ambiente, a exemplo da mineração.

\section{REFERÊNCIAS}

AGÊNCIA NACIONAL DE ÁGUAS. Plano integrado de recursos hídricos da bacia hidrográfica do rio Doce: relatório executivo. Brasília: ANA, 2016.

ANDRADE, M. C. A questão do território no Brasil. 2. ed. São Paulo: Hucitec, 2004.

ARCURI, M.; LAIA, P. O; SUNER, R. Territórios e patrimônios na lama das negociações: desafios para a museologia comunitária na Barragem de Fundão. Arquivos do Museu de História Natural e Jardim Botânico, Belo Horizonte: UFMG, v. 24, n. 1, p. 209-244, 2015.

AUGUSTO, D. M.; FEITOSA, M. Z.; BONFIM, Z. A. C. A utilização dos mapas afetivos como possibilidade de leitura do território no CRAS. Estudos Interdisciplinares em Psicologia, Londrina, v. 7, n. 1, p. 145-158, jun. 2016.

BARBOSA, F. A. R.; MAIA-BARBOSA, P. M.; NASCIMENTO, A. M. A. et. al. O desastre de Mariana e suas consequências sociais, econômicas, políticas e ambientais: porque evoluir da abordagem de Gestão dos recursos naturais para Governança dos recursos naturais. Arquivos do Museu de História Natural e Jardim Botânico, Belo Horizonte: UFMG, v. 24, n. 1, p. 159-182, 2015.

BECKER, H. S. Falando da sociedade: ensaios sobre as diferentes maneiras de representar o social. Rio de Janeiro: Jorge Zahar, 2009.

BOURDIEU, P. O poder simbólico. 12 ed. Rio de Janeiro: Bertrand Brasil, 2009.

BRANDÃO, C. Pactos em territórios: escalas de abordagem e ações pelo desenvolvimento. Organizações \& Sociedade, [S./l.], v.15, n.45, p. 145-158, 2008.

BRASIL/MINISTÉRIO DE MINAS E ENERGIA. Estudos para licitação da expansão da geração: AHE Belo Monte - Avaliação Técnica. Brasília. Empresa de Pesquisa Energética, 2009. 
ROCHA NETO, J. M.

Os "sem rio": populações desterritorializadas pelo desastre ambiental de Mariana

BRUNET, R., FERRAS, R.; THÉRY, H. Les mots de la géographie, dictionnaire critique. Montpellier/Paris: Reclus/La Documentation Française, 1992.

CLAVAL, P. Terra dos Homens. São Paulo: Contexto, 2010.

COELHO, T. P. Projeto Grande Carajás: trinta anos de desenvolvimento frustrado. Marabá, PA: Editorial iGuana, 2015.

COORÊA, R. L. Trajetórias geográficas. São Paulo: Bertrand Brasil, 2001.

CUNHA, L. H.; SILVA, J. I. A. O.; NUNES, A. M. B. A proteção da Natureza em assentamentos rurais e nas RPPN's: conflitos ambientais e processos de territorialização. Revista Raízes, [S./1.], v. 27, n. 1, p. 80-96, 2008.

DEMATTEIS, G. Geografia Democrática, território e desenvolvimento local. Revista Formação, n.12, v.2, p.11-26, 2005.

DNPM. Distribuição CFEM. Disponível em: https://sistemas.anm.gov.br/arrecadacao/extra/relatorios/distribuicao_cfem_muni.aspx?ano=2 $\underline{020 \& u f=P A}$

FERREIRA, S. R. B. Marcas da colonialidade do poder no conflito entre a mineradora Samarco, os povos originários e comunidades tradicionais do Rio Doce. In: MILANEZ, B.; Losekan, C (Orgs.). Desastre no Vale do Rio Doce: antecedentes, impactos e ações sobre a destruição. Rio de Janeiro: Folio Digital: Letra e Imagem, 2016. p. 267-310.

FREITAS, Carlos Machado de et al. Desastres em barragens de mineração: lições do passado para reduzir riscos atuais e futuros. Epidemiol. Serv. Saúde, Brasília, v. 28, n. 1, p. 1-4, mar. 2019.

FUNDAÇÃO JOÃO PINHEIRO. PIB de Minas Gerais: anexo estatístico 2010-2013. Disponível em: http://www.fjp.mg.gov.br/index.php/produtos-e-servicos1/2745produtointerno-bruto-de-minas-gerais-pib-2.

GUEDES, A. D. Lutas por terra e território, desterritorialização e território como forma social. Revista Brasileira de Estudos Regionais, Recife, v.18, n.1, p.23-39, Jan-abr. 2016.

HAESBAERT, R. O mito da desterritorialização: do fim dos territórios à multiterritorialidade. Rio de Janeiro: Bertrand Brasil, 2006.

LAMEIRAS, A. A. Desterritorialização e reorganização das geografias Pessoais: o caso do desemprego. Ensaio metodológico. 2013. 60 f. Dissertação (Mestrado em Geografia), Departamento de Geografia, da Faculdade de Letras da Universidade de Coimbra, Coimbra, 2013.

L'ESTOILE, B. SIGAUD, L. Caderno de fotos: fotografia e pesquisa de campo. Ocupações de terra e transformações sociais: uma experiência etnográfica coletiva. Rio de Janeiro: FGV, 2006, p. 190-228. 
ROCHA NETO, J. M.

Os "sem rio": populações desterritorializadas pelo desastre ambiental de Mariana

MARTINS, G. I; CLEPS JÚNIOR, J. Nas tramas do discurso: possibilidades teóricas e metodológicas em Michel Foucault. MARAFON, G. J. et. Al (Orgs.). Pesquisa qualitativa em geografia: reflexões teórico-conceituais e aplicadas. Rio de Janeiro: EdUERJ, 2013. p. 69-88.

MINISTÉRIO DE MINAS E ENERGIA. Estudos para licitação da expansão da geração: AHE Belo Monte. Rio de Janeiro: EPE, 2010. Disponível em: https://www2.aneel.gov.br/aplicacoes/editais_geracao/documentos/062009ANEXO\%209\%20-\%20Relat\%C3\%B3rio\%20EPE-DEE-RE-019-2010r0\%20Conex\%C3\%A3o\%20do\%20UHE\%20Belo\%20Monte-Rev.pdf

MIRANDA, R. S. Ecologia política e processos de territorialização. Revista Sociedade e Estado, [S./l.], v. 28, n. 1, p. 142-161, Jan/Abr, 2013.

MOREIRA, R. O espaço e o contra-espaço: as dimensões territoriais da sociedade civil e do Estado, do privado ao público na ordem espacial burguesa. SANTOS, M. et. al. (Orgs.). Território, Territórios: ensaios sobre o ordenamento territorial. Rio de Janeiro: DP\&A. 2006. p. 71-107.

PASSOS, F. L.; COELHO, P.; DIAS, A. (Des)territórios da mineração: planejamento territorial a partir do rompimento em Mariana, MG. Cad. Metrópole, São Paulo, v. 19, n. 38, pp. 269-297, jan/abr 2017.

RAFFESTIN, C. Por uma geografia do poder. São Paulo: Editora Ática, 1993.

SANTOS, M. A Natureza do Espaço. Técnica e Tempo. Razão e Emoção. São Paulo, Hucitec, 1996.

SAQUET, M. A.; SILVA, S. S. Milton Santos: concepções de geografia, espaço e território. Geo UERJ - Ano 10, Rio de Janeiro, v.2, n.18, p. 24-42, 2008.

SOUZA SANTOS, B. Para além do pensamento abissal: das linhas globais a uma ecologia de saberes. Novos estudos - Cebrap, São Paulo, n. 79, p. 71-94, 2007.

TERRA BRASIS RESEGUROS. Terra Report Edição Especial: Mariana. Disponível em: http://www.terrabrasis.com.br/Content/pdf/.

TUAN, Yi-fu. Paisagens do medo. (Tradução de Lívia de Oliveira). São Paulo: UNESP, 2005.

VALENCIO, N.; SIENA, M.; MARCHEZINI, V. Abandonados nos desastres: uma análise sociológica de dimensões objetivas e simbólicas de afetação de grupos sociais desabrigados e desalojados. Brasília: Conselho Federal de Psicologia, 2011.

VIANA, M. B. Avaliando Minas: índice de sustentabilidade da mineração (ISM). 2012. 372 f. Tese (Doutorado em Política e Gestão Ambiental), Centro de Desenvolvimento Sustentável da Universidade de Brasília, Brasília, 2012.

Revista Cerrados, Montes Claros/MG, v. 18, n. 02, p. 152-182, jul./dez.-2020. 
Os "sem rio": populações desterritorializadas pelo desastre ambiental de Mariana

VIEYRA, J. C.; MASSON, M. Gobernanza con transparencia en tiempos de abundancia: experiencias de las industrias extractivas en América Latina y el Caribe. Juan Cruz Vieyra, Malaika Masson, Editores. 2015.

WANDERLEY, L. J. M. As múltiplas relações espaciais de poder no espaço da mineração. Anais do X Encontro de Geógrafos da América Latina. Universidade de São Paulo, 2005, p. 16449-16472.

\section{Autor}

João Mendes da Rocha Neto - É Graduado em Geografia; Mestre e Doutor em Administração pela Universidade do Rio Grande do Norte (UFRN). Atualmente é Professor do Programa de Pós-graduação em Administração da Universidade de Brasília, na área de Administração Pública e Políticas Públicas. É Servidor Público Federal do Ministério da Economia, cedido ao Ministério do Desenvolvimento Regional.

Artigo recebido em: 13 de junho de 2020.

Artigo aceito em: 17 de agosto de 2020.

Artigo publicado em: 19 de agosto de 2020. 